\title{
Correlation between clinical evaluation of liver size versus ultrasonography evaluation according to body mass index (BMI) and biotypes
}

\author{
ROSEMERI MAURICI DA SILVA ${ }^{1}$, RODRIGO BECKER PEREIRA ${ }^{2, \mathrm{a}}$, \\ MARCELO VASCONCELOS SIQUEIRA', a
}

\begin{abstract}
Background: Body weight may influence liver size. Aim: To determine the correlation between clinical and ultrasound evaluation of the liver size according to body mass index (BMI). Material and Methods: A cross-sectional study of 81 subjects aged $25 \pm 6$ years (43 females). Two percussion measurements were taken and ultrasonography was performed on the same site demarcated by percussion. Results: Mean BMI was $23 \pm 4 \mathrm{~kg} / \mathrm{m}^{2}$. Nineteen individuals (23.5\%) had a BMI $\geq 25 \mathrm{~kg} / \mathrm{m}^{2}$. There was a significant difference between the values of liver size obtained by clinical and ultrasound methods. The correlation coefficient between the liver size obtained by clinical and ultrasound methods was 0.419 ( $p<0.01)$. No significant differences in liver size were observed, between subjects with a BMI below or over $25 \mathrm{~kg} / \mathrm{m}^{2}$. In all subjects, regardless of BMI, there was a statistically significant difference between the mean sizes obtained by both methods. The correlation coefficients between both methods in subjects with a BMI $\leq 25 \mathrm{Kg} / \mathrm{m}^{2}$ and their counterparts with higher BMI were 0.47 and 0.03, respectively. Conclusions: There are significant differences in liver size obtained by clinical examination and ultrasound. Only in subjects with $B M I \leq$ $25 \mathrm{~kg} / \mathrm{m}^{2}$, the correlation between the two techniques is significant.
\end{abstract}

(Rev Med Chile 2010; 138: 1495-1501).

Key words: Liver; Physical examination; Ultrasonography.

\section{Comparación de la medición del tamaño del hígado por ultrasonografía y mediante examen físico}

Introducción: El peso corporal puede tener influencia sobre el tamaño del hígado. Objetivo: Determinar el tamaño del hígado mediante examen físico y ultrasonido en sujetos con distinto índice de masa corporal (IMC). Material y Métodos: Estudio transversal de 81 individuos de $25 \pm 6$ años (43 mujeres). Se tomaron dos medidas del hígado por percusión y la ultrasonografía se efectuó en el mismo sitio marcado por la percusión. Resultados: El IMC promedio de los individuos fue de $23 \pm 4 \mathrm{~kg} / \mathrm{m}^{2}$. Diecinueve sujetos (23,5\%) tenían un $I M C \leq 25 \mathrm{~kg} / \mathrm{m}^{2}$. Se observaron diferencias significativas entre las mediciones obtenidas por examen físico y ultrasonografía en todos los sujetos, no importando el valor de IMC. No se observaron diferencias

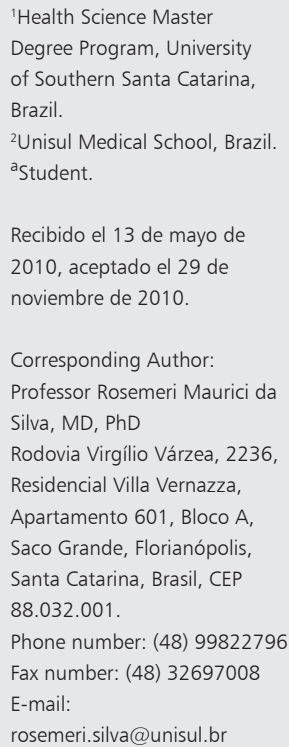


en el tamaño del hígado entre sujetos con un IMC menor o mayor a $25 \mathrm{~kg} / \mathrm{m}^{2}$. Los coeficientes de correlación entre los dos métodos en sujetos con un IMC $\leq 25 \mathrm{~kg} / \mathrm{m}^{2}$ $y$ aquellos con valores más altos fueron 0,47 y 0,03, respectivamente. Conclusiones: Las mediciones clínicas y ultrasonográficas del tamaño del hígado difieren significativamente. Sólo en sujetos con un IMC $\leq 25 \mathrm{~kg} / \mathrm{m}^{2}$, ambas mediciones tienen una correlación significativa.

T he liver is the largest gland in the human body and is found in the intra-abdominal cavity. It weighs around $1500 \mathrm{~g}$ and has higher density among male individuals. Its function is to filter and store blood, metabolize carbohydrates, proteins, hormones and strange chemicals; to form bile, store vitamins and iron; and to produce clotting factors $^{1-5}$.

The liver has two anatomical parts, the right lobe and left lobe, separated by an imaginary line that runs from the gallbladder fossa into the inferior vena cava ${ }^{1,3}$.

During a clinical interview, a number of liverrelated disorder complaints may be reported by a patient; pain is the main complaint, usually located in the abdominal right upper quadrant or epigastrium ${ }^{6,7}$.

Following the clinical interview, patients will undergo physical examination, when inspection, percussion, palpation and auscultation of the liver can be made ${ }^{6}$. Physical examination addresses the liver in a projection surface that covers almost the entire chest wall ${ }^{6,8}$. After inspection, percussion is performed with the aim of determining the liver upper boarder and, when possible, the lower boarder, estimating liver size ${ }^{6}$. Normal liver volume is proportional to body size. The normal adult liver spans 10 to $12 \mathrm{~cm}$ for men and 8 to $10 \mathrm{~cm}$ for women ${ }^{7}$. Generally, it can vary between 6 and 12 $\mathrm{cm}$ in all subjects when percussion is performed in the midclavicular line 9 .

Percussion should start gently in the midclavicular line just inferior to the second rib, starting from the pulmonary clear sound until dullness liver, which occurs approximately in the fifth intercostal space and corresponds to the diaphragm muscle on the liver dome. The patient should be positioned supine and the examiner always on his right ${ }^{9}$. In women, the breast should be gently moved upwards so as not to compromise the percussion. The last dullness points found on percussion in the imaginary line from midclavicular to craniocaudal direction will determine the liver lower boarder ${ }^{10,11}$. The path joining the two points, the onset of liver dullness being the first and the limit point of dullness at the lower edge the second, is the supposedly the real liver size ${ }^{6}$.

The liver volume can be measured by various techniques such as radiography, scintigraphy, computed tomography, magnetic resonance and ultrasonography ${ }^{12,13}$. Ultrasonography is the first imaging method to assess hepatic affections, which has a number of key advantages, such as low cost, rapid implementation, risk-free, non-invasive, no use of ionizing radiation or sedation that facilitates technical performance, especially when it comes to children ${ }^{12,13}$.

In the literature, there are no studies comparing liver measurement with biotype of participants determined by Charpy's angle, but there are reports that body weight influences liver size. Kratzer and colleagues ${ }^{14}$ also found a correlation between body mass index and liver measurement, and discovered that the higher the individual's BMI, the larger the liver size. Niederau and colleagues ${ }^{15}$ also found that besides the surface of body mass, body weight influences liver size. Konus and colleagues ${ }^{16}$ found a correlation $(\mathrm{r}=0.80)$ between body weight and liver dimensions. They discovered that height is the best parameter for correlation with longitudinal liver size in the midclavicular line in children $(\mathrm{r}=$ 0.85 ), and concluded that the greater the child's height, the larger the longitudinal extent of the liver. Altunkaynak and Altunkaynak ${ }^{17}$ recently concluded that excessive weight is a determining factor for hepatomegaly, especially in females. The determination of the accuracy of physical examination techniques is highly desirable, since the changes found on physical examination will determine further investigation exams. This study was carried out to determine the correlation between clinical assessment of liver measurement versus ultrasonographic evaluation according to BMI and different biotypes. 


\section{Patients and Methods}

A cross-sectional study was conducted between August 2008 and April 2009, at the Nossa Senhora da Conceição Hospital Diagnostic Center in Tubarão, State of Santa Catarina, Brazil. The target population consisted of number of patients that would undergo abdominal ultrasound examination. The study sample consisted of 81 male and female patients, selected according to their medical appointment scheduling. The study included those over eighteen years of age. All patients were informed about the research project and signed a free consent form, in addition to being registered in an inclusion form. Exclusion criteria included patients with chest deformities, ascites, those who had undergone right pneumonectomy, patients with Chilaiditi's syndrome detected through ultrasonography (transposition of a loop of large intestine between the diaphragm and the liver), and any other condition that could affect the physical examination or ultrasonography, as well as those who did not agree to participate in the study. Individuals excluded from the study were replaced by randomly selected patients to fill the total sample size.

All participants underwent two procedures at the same occasion, the physical examination and abdominal ultrasound examination. First, hepatic percussion was performed towards the midclavicular line, where the hepatic dullness beginning and ending points were marked. The path between these points was measured in centimeters. Two percussion measurements were taken; the average between them determined the patient's liver measurement by clinical method. At this point the examiner evaluated the patient's body type through the Charpy's angle (formed by the intersection of the lower ribs) classification and collected anthropometric data (body weight in grams and height in centimeters) to calculate the BMI of each participant. Then, ultrasonography was performed on the site marked by percussion, determining the patient's ultrasonic measurement of liver size. All participants were evaluated by an observer with knowledge and training in clinical method and by a physician expert trained in ultrasound technique.

A database was created and statistical analysis was performed using SPSS 16.0 software. The variables were summarized as percentage or ave- rage as indicated. Correlation between hepatic measurements undertaken by clinical examination and those obtained by ultrasound method were calculated using Pearson's correlation coefficient. The research project was approved by the Human Research Ethics Committee of Unisul, under the code number 08.501.4.01.III.

\section{Results}

Eighty-one subjects, all Caucasians, were consecutively evaluated. Forty-three $(53.1 \%)$ were females and $38(46.9 \%)$ were males. Mean age was 25 years $(\mathrm{SD} \pm 6)$, with age ranging between 19 and 54 years. Mean height was $170 \mathrm{~cm}(\mathrm{SD} \pm 9)$, with height ranging between 152 and 188 centimeters. Mean weight was 65,560 grams (SD $\pm 13,554)$, with weight ranging between 43,000 and 103,000 grams. Mean BMI was $23 \mathrm{~kg} / \mathrm{m}^{2}(\mathrm{SD} \pm 4)$, ranging between 17 and $38 \mathrm{~kg} / \mathrm{m}^{2}$. When using BMI of 25 $\mathrm{kg} / \mathrm{m}^{2}$ as a cutoff point, 19 subjects $(23.5 \%)$ reached values higher than or equal to 25 , while 62 subjects $(76.5 \%)$ had values lower than 25. Biotype distribution according to Charpy's angle was 13 (16\%) brevilinear, 31 (38.3\%) normolinear, and $37(45.7 \%)$ longilinear individuals.

There was a statistically significant difference between the values of liver size obtained by clinical examination and ultrasound method, demonstrating a tendency towards underestimation of liver size by clinical evaluation, as shown in Table 1 .

There was no statistically significant difference of liver measurement obtained by percussion, when stratified by gender $(\mathrm{p}=0.861)$. Similarly, there was no statistically significant difference of liver measurement obtained by ultrasonography when stratified by gender $(p=0.389)$. The results are shown in Table 2.

Pearson's correlation coefficient between liver size obtained by clinical examination and ultrasound method was 0.419 ( $\mathrm{p}<0.01$ ), which is considered a good correlation. There was no statistically significant difference of liver measurement obtained by percussion, when stratified by BMI cutoff point $(\mathrm{p}=0.576)$. Similarly, no statistically significant difference of liver measurement obtained by ultrasonography when stratified by BMI cutoff point $(\mathrm{p}=0.905)$. The results are shown in Table 3.

The values of liver measurement obtained by 
Table 1. Results of liver measurement in centimeters through clinical examination and ultrasound method

\begin{tabular}{|lcc|}
\hline Values & $\begin{array}{c}\text { Clinical } \\
\text { Examination }\end{array}$ & $\begin{array}{c}\text { Ultrasound } \\
\text { Method }\end{array}$ \\
\hline Average & 8.8 & 11.6 \\
Standard Deviation & 1.7 & 2.6 \\
Minimum & 5.3 & 6 \\
Maximum & 15 & 16.5 \\
\hline
\end{tabular}

$p=0.000$

Table 2. Values of liver measurement in centimeters through clinical examination and ultrasound method stratified by gender

\begin{tabular}{|c|c|c|c|}
\hline Gender & n $\quad(\%)$ & $\begin{array}{c}\text { Ultrasonography } \\
\text { Mean ( } \pm \text { DP) }\end{array}$ & $\begin{array}{c}\text { Percussion } \\
\text { Mean ( } \pm \text { DP) }\end{array}$ \\
\hline Female & $43(53.1)$ & $11.9( \pm 2.5)$ & $8.7( \pm 1.8)$ \\
\hline Male & 38 (46.9) & $11.4( \pm 2.7)$ & $8.8( \pm 1.7)$ \\
\hline$p$ & & 0.389 & 0.861 \\
\hline
\end{tabular}

Table 3. Values of liver measurement in centimeters through clinical examination and ultrasound method stratified by BMI

\begin{tabular}{|c|c|c|c|}
\hline $\begin{array}{l}\text { BMI } \\
\left(\mathbf{k g} / \mathbf{m}^{2}\right)\end{array}$ & n $\quad(\%)$ & $\begin{array}{c}\text { Ultrasonography } \\
\text { Mean ( } \pm \text { DP) }\end{array}$ & $\begin{array}{c}\text { Percussion } \\
\text { Mean ( } \pm \text { DP) }\end{array}$ \\
\hline$\geq 25$ & $19(23.5)$ & $11.6( \pm 2.9)$ & $8.6( \pm 1.5)$ \\
\hline$<25$ & $62(76.5)$ & $11.7( \pm 2.6)$ & $8.8( \pm 1.8)$ \\
\hline$p$ & & 0.905 & 0.576 \\
\hline
\end{tabular}

Table 4. Values of liver measurement in centimeters through clinical examination and ultrasound method according to the biotype

\begin{tabular}{|lccc|}
\hline Biotype & $\mathbf{n}(\%)$ & $\begin{array}{c}\text { Ultrasonography } \\
\text { Mean ( } \pm \text { DP) }\end{array}$ & $\begin{array}{c}\text { Percussion } \\
\text { Mean ( } \pm \text { DP) }\end{array}$ \\
\hline Brevilinear & $13(16)$ & $12.5( \pm 2.4)$ & $8.2( \pm 0.8)$ \\
Longilinear & $37(45.7)$ & $12.3( \pm 1.6)$ & $8.9( \pm 1.5)$ \\
Normolinear & $31(38.3)$ & $10.5( \pm 3.2)$ & $8.7( \pm 2.2)$ \\
p & & 0.005 & 0.470 \\
\hline
\end{tabular}

clinical examination and ultrasound method according to the biotype are shown in Table 4.

Pearson's correlation coefficients between BMI and liver measurement obtained by percussion and by ultrasonography were -0.092 and 0.01 , respectively, which is not statistically significant. When assessing individuals with BMI greater than or equal to 25 , there was a statistically significant difference between the mean values obtained by both methods $(\mathrm{p}=0.001)$. In this group of individuals the correlation between the two methods showed a Pearson's correlation coefficient of 0.035 , which is not statistically significant.

In the group of individuals with BMI less than 25, there was a statistically significant difference between the mean values obtained by both methods $(p=0.000)$, but in this group the correlation between the two methods showed a Pearson's correlation coefficient of 0.473 , with statistical significance $(\mathrm{p}<0.01)$.

\section{Discussion and Conclusion}

In this study, there was a good correlation between liver size obtained by clinical examination and ultrasound method $(r=0.419)$. Castell and colleagues ${ }^{11}$ also obtained a good correlation $(r=0.77)$ between percussion and liver measurement obtained by image in their study of 116 healthy adults, but they did not mention which imaging standard was used for comparison. Sapira and colleagues ${ }^{18}$ found a Pearson's correlation coefficient of 0.64 in a study of 96 healthy subjects, when comparing the values obtained by percussion with ultrasound measurement. Rajnish and colleagues ${ }^{19}$ studied the accuracy of palpation and percussion compared to ultrasonography in a sample of 180 patients and concluded that the 
clinical method alone is not sufficiently able to confirm or exclude the presence of hepatomegaly.

In this study, mean liver measurement obtained by clinical examination on the midclavicular line underestimated the mean value obtained by ultrasonography, which is also described in the literature by Sullivan and colleagues ${ }^{20}$ in studies with adult patients. In another study of 21 children, the same result was not found, i.e., mean clinical liver measurement by percussion and auscultation overestimated mean ultrasonic measurement ${ }^{21}$.

It is known that several factors can interfere with liver measurement, such as weight, height, age, gender, percussion technique, site of percussion, phase of respiration, anatomical abnormalities, obesity, large-volume ascites, cirrhosis, tumors, hepatomegaly, personal habits and patient's position during the examination ${ }^{11,13,14,18,22-25}$.

In a review, Meidel and Ende ${ }^{22}$ reported that the percentage of palpable liver in healthy subjects is $28 \%$. Rajnish and colleagues ${ }^{19}$ found a good correlation between the three examiners ( $82 \%$ to $84 \%$ ) in determining palpable liver in 36 patients with increased liver by ultrasonography, and concluded that $20 \%$ of patients had palpable livers. Sullivan and colleagues ${ }^{20}$ concluded that clinical evaluation of liver can be difficult due to the hepatic shape, position and axis. Even the percussion angle of the examiner's fingers may interfere with liver measurement, as well as the force applied during the percussion $^{26,27}$. Rosenfield and colleagues ${ }^{28}$ studied the correlation between scintigraphy and palpation in 100 adult patients and concluded that palpation can be changed with the patient in orthostatic or supine position. Jackson and colleagues ${ }^{24}$ also concluded that the patient's position interferes with liver measurement. In a study among observers, Naylor and colleagues ${ }^{29}$ concluded that there are clinical limitations to accurately determine the midclavicular line. All these factors may lead to an inaccurate identification of the liver boarders, thus interfering greatly with the results.

In this study, mean liver size measured by clinical method was $8.8 \pm 1.7 \mathrm{~cm}$ on the midclavicular line. Castell and colleagues ${ }^{11}$ found a very close value in adults. The mean value was $9.75 \pm 2 \mathrm{~cm}$ when using light percussion only.

The final mean value of ultrasound-measured liver size was $11.6 \pm 2.6 \mathrm{~cm}$. In a study of 915 healthy participants, Niederau and colleagues ${ }^{15}$ also found similar values; the mean value was
$10.5 \pm 1.5$ on the midclavicular line. In a random sample of 2,080 participants including healthy and ill adults, Kratzer and colleagues ${ }^{14}$ found an ultrasonic mean value of $14 \pm 1.7 \mathrm{~cm}$ on the midclavicular line.

This study found no significant differences in liver measurement by clinical examination and ultrasound method between male and female individuals $(\mathrm{p}>0.05)$. This is not true in the literature. In a study of 915 healthy adults, Niederau and colleagues ${ }^{15}$ found a significant difference between genders, but they did not specify the measurement values. In a study of 116 adults, Castell ${ }^{11}$ concluded that gender is a determining factor for liver size. They discovered that men have larger liver size than women and they even proposed a formula for correcting liver measurement by clinical percussion for each gender. In a sample of 2,080 adults, Kratzer and colleagues ${ }^{14}$ found a significant difference for ultrasound liver measurement between male and female individuals. Mean value for men was $14.5 \pm 1.6 \mathrm{~cm}$ and $13.5 \pm 1.7 \mathrm{~cm}$ for women. In a study of 307 children aged between 5 days and 16 years, Konus and colleagues ${ }^{16}$, however, found no significant size difference in hepatic lobes.

Mean ultrasound-measured liver size in longilinear, normolinear and brevilinear individuals was $12.3 \pm 1.6 \mathrm{~cm}, 10.5 \pm 3.2 \mathrm{~cm}$ and $12.5 \pm 2.4$ $\mathrm{cm}$, respectively, the difference being statistically significant $(\mathrm{p}=0.005)$. The difference in clinical liver measurement according to the biotype was not statistically significant $(\mathrm{p}=0.470)$. These results suggest that there is no relationship between liver volume and body size. In the literature, there are no studies comparing liver measurement with the biotype of participants determined by Charpy's angle, however, there are reports that body weight influences liver size.

Pearson's correlation coefficients between BMI and liver measurement obtained by percussion and by ultrasound were -0.092 and 0.01 , respectively, which did not show statistical significance. Assessing individuals with BMI greater than or equal to 25 , there was a statistically significant difference between the mean values obtained by both methods $(\mathrm{p}=0.001)$. In this group of individuals, the correlation between the two methods showed a Pearson's correlation coefficient of 0.035 , not statistically significant. In the group of individuals with BMI less than 25, there was a statistically significant difference between the mean values 
obtained by both methods $(\mathrm{p}=0.000)$, but in this group the correlation between the two methods showed a Pearson's correlation coefficient of 0.473 , with statistical significance $(\mathrm{p}<0.01)$.

Kratzer and colleagues ${ }^{14}$ found a correlation between body mass index and liver measurement, and discovered that the higher the body mass index of the subject, the greater the liver measurement. Niederau and colleagues ${ }^{15}$ observed that body weight as well as body mass index influence liver size. Konus and colleagues ${ }^{16}$ found a correlation coefficient of 0.80 between child's weight and liver size. They found that height is the best parameter for the correlation with longitudinal liver size in the midclavicular line in children $(\mathrm{r}=0.85)$, and concluded that the greater the child's height, the greater the longitudinal extent of the liver. Altunkaynak and colleagues ${ }^{17}$ recently concluded that excessive body weight is a determining factor for hepatomegaly, especially in females.

The results of this study show that liver measurement obtained by clinical examination correlates well with ultrasound method, but underestimates the actual liver size in adults, which can be demonstrated by the statistically significant difference between the final mean value obtained by clinical observation and that obtained by ultrasound method. In subjects with BMI greater than 25, the correlation between the two techniques was not good and it can be inferred that clinical method is less accurate for this group of patients.

\section{References}

1. Gardner E, Gray DJ, O’Rahilly R. Anatomia: estudo regional do corpo humano. $4^{\mathrm{a}} \mathrm{ed}$. Rio de Janeiro: Guanabara Koogan; 1988.

2. Gray H. Anatomia. $37^{\mathrm{a}}$ ed. Rio de Janeiro: Guanabara Koogan; 1995.

3. Moore KL, Dalley AF. Anatomia orientada para a clínica. $4^{\text {a }}$ ed. Rio de Janeiro: Guanabara Koogan; 2001.

4. Dângelo JG, Fattini CA. Anatomia humana sistêmica e segmentar para o estudante de medicina. $2^{2}$ ed. São Paulo: Atheneu; 1998.

5. Guyton AC, Hall JE. Tratado de Fisiologia Médica. 10ª ed. Rio de Janeiro:Guanabara Koogan;2002.

6. Porto CC. Semiologia médica. 4a ed. Rio de Janeiro: Guanabara Koogan; 2004.

7. Epstein O, Perkini GD, Bono DP, Cookson J. Exame clínico. 2a ed. Porto Alegre: Artmed; 1998.
8. Bates B, Bickley LS, Hockelman RA. Propedêutica médica. 6a ed. Rio de Janeiro: Guanabara Koogan; 1998.

9. Silva RM. Semiologia para o estudante de medicina. Tubarão: Unisul; 2005.

10. Swartz MH. Tratado de semiologia médica: história e exame clínico. $5^{\text {a }}$ ed. Rio de Janeiro: Elsevier; 2006.

11. Castell DO, O’Brien KD, Muench H, Chalmers TC. Eastimation of liver size by percussion in normal individuals. Ann Int Med 1969; 70: 1183-9.

12. Vazozzo DCP, Rocha DC, Cerri GG. Ultra-sonografia abdominal. $1^{\text {a }}$ ed. São Paulo:Sarvier;1993.

13. Rocha SMS, Oliveira IRS, Widman A, Chisman BSK, Fukushima JT, Oliveira LAN, et al. Hepatometria ultrasonográfica em crianças: proposta de novo método. Radiol Bras 2003; 36: 63-70.

14. Kratzer W, Fritz V, Mason RA, Haenle MM, Kaechele V. Factors affecting liver size: a sonographic survey of 2080 subjects. J Ultrasound Med 2003; 22: 1155-61.

15. Niederau C, Sonnemberg A, Muller JE, Erckenbrecht JF, Scholten T, Fritsch WP. Sonographic measurements of the normal liver, spleen, pancreas, and portal vein. Radiology 1983; 149: 537-40.

16. Konus Ö, Özdemir A, Akkaya A, Erbas G, Celik H, Isik $\mathrm{S}$. Normal liver, spleen, and kidney dimensions in neonates, infants, and children: evaluation with sonography. Am J Roentg 1998; 171: 1693-8.

17. Altunkaynak BZ, Altunkaynak ME. Relationship of body weight and volume of liver: a morphometrical and stereological study. Saudi Med J 2007; 28: 891-5.

18. Sapira JD, Williamson DL. How big is the normal liver? Arch Int Med 1979; 139: 971-3.

19. Rajnish J, Amandeep S, Namita J, Madhular P, Kalantri SP. Accuracy and reliability of palpation and percussion for detecting hepatomegaly: a rural hospital-based study. Indian J Gastroenterol 2004; 23: 171-4.

20. Sullivan S, Krasner N, Williams R. The clinical estimation of liver size: a comparison of techniques and an analysis of the source of error. BMJ 1976; 30: 1042-3.

21. Callahan CW. Simultaneous percussion auscultation technique for the determination of liver span. Arc Ped Adol Med 1994; 148: 873-5.

22. Meidl EJ, Ende J. Evaluation of liver size by physical examination. J Gen Int Med 1993; 8: 635-7.

23. Gilbert VE. Detection of the liver below the costal margin: comparative value of palpation, light percussion, and auscultatory percussion. South Med J 1994; 87: 182-6.

24. Jackson ML, Zuckier L, Goldfarb CR, Ongseng F. Effect of patient positioning on liver size estimation. J Nuclear Med 1986; 27: 1632-4.

25. Chan SC, Liu CL, Lo CM, Lam BK, Lee EW, Wong Y, Fan 
ST. Estimating liver weight of adults by body weight and gender. World J Gastroenterol 2006; 12: 2217-22.

26. Kingra GS. Percussion of the liver. NEJM 1970; 283: 101.

27. Al-Awqati Q. Percussion of the liver. Ann Intern Med 1969; 71: 868 .

28. Rosenfield AT, Laufer I, Schneider PB. The significance of a palpable liver. A correlation of clinical and radioisotope studies. Am J Roentg, Radium Therapy, and Nuclear Med 1974; 122: 313-7.

29. Naylor CD, McCormack DG, Sullivan SN. The midclavicular line: a wandering landmark. Can Med Ass J 1987; 136: $48-50$. 